\title{
PERANG BUBAT, REPRESENTASI SEJARAH ABAD KE-14 DAN RESEPSI SASTRANYA
}

\section{BUBAT WAR, THE 14TH CENTURY'S REPRESENTATION OF HISTORICAL AND LITERATURE RECEPTION}

\author{
Yeni Mulyani Supriatin \\ Balai Bahasa Jawa Barat, Jln. Sumbawa Nomor 11, Bandung \\ e-mail: yeni.mulyani@yahoo.com
}

\begin{abstract}
Abstrak
Penelitian ini bertujuan mengungkap peristiwa Perang Bubat yang terjadi pada abad ke-14 atau tahun 1357 M dan resepsi sastranya. Masalah yang dibahas adalah bagaimana latar belakang terjadinya Perang Bubat, reaksi, dan tanggapannya. Teori yang digunakan adalah resepsi sastra. Metode untuk pengumpulan data adalah kualitatif dengan menerapkan prinsip resepsi sastra. Hasil penelitian menggambarkan bahwa terjadinya Perang Bubat disebabkan Raja Sunda tidak tunduk pada kehendak Gajah Mada dan Gajah Mada ingin menyatukan Nusantara. Resepsi sastra terhadap Perang Bubat dapat dikelompokkan menjadi tiga, yaitu resepsi dari aspek kesejarahannya, resepsi pengaruhnya terhadap penciptaan karya baru, dan resepsi terhadap struktur sastra. Simpulan penelitian ini adalah peristiwa Bubat diresepsi setelah dua abad berlalu, yaitu pada abad ke-16 dan peristiwa tersebut diresepsi ulang pada abad ke-20-an. Hasil resepsi sastra dari abad ke-18 sampai dengan abad ke-20 cukup beragam. Keberagaman resepsi itu menunjukkan bahwa terdapat perbedaan horizon harapan pembaca.
\end{abstract}

Kata kunci: Perang Bubat; resepsi sastra; dan horizon harapan.

\begin{abstract}
This study aims to reveal the events of the Bubat War that occurred in the 14th century or the year $1357 A D$ and literary receptions that emerged after the incident occurred. The issue discussed is how the background of the Bubat War and the reactions and responses to the event through literary receptions. The theory used in analyzing data is literary receptions. The method used for data collection is qualitative by applying the principle of literary receptions. The results of this study illustrate that the background of the Bubat War have two versions and both controversial, the first version because the King of Sunda entourage do not obey to the will of Gajah Mada, on the other hand, the second version is that Gajah Mada tactics in unifying the archipelago while the Kingdom of Sunda is a state that has not been submitted. Literary receptions to the War of Bubat can be grouped into three, they are the reception of its historical aspect, the reception of its influence on the creation of new works, and the reception of the literary structure. The conclusion of this research is Bubat event was perceived after two centuries passed, in the 16 th century and the event was redrawn in the 20th century. Results of literary receptions in the 18 th century until the 20th century quite diverse. The diversity of the receptions shows the difference in the horizon of readers' expectations.
\end{abstract}

Keywords: Bubat War; literary receptions; and the expectation horizon.

\section{A. PENDAhuluan}

Hingga abad ke-14, Kerajaan Sunda masuk kategori kerajaan besar dan tidak terkalahkan. Sampai akhirnya pecah Perang Bubat pada tahun $1357 \mathrm{M}$ atau pada abad ke-14. Perang Bubat berawal dari keinginan Prabu Hayam Wuruk memperistri Dyah Pitaloka Citraresmi, Putri Prabu Linggabuana. Selain terpesona pada wajah putri yang cantik, Prabu 
Hayam Wuruk ingin mengikat persekutuan dengan Negeri Sunda. Setelah melamar Dyah Pitaloka, Prabu Hayam Wuruk memutuskan bahwa upacara pernikahan akan berlangsung di Majapahit.

Meskipun mendapat tantangan dari dewan kerajaan, Prabu Linggabuana, Dyah Pitaloka, dan rombongan pergi ke Majapahit. Rombongan itu diterima dan ditempatkan di Pesanggrahan Bubat.

Mahapatih Gajah Mada yang ingin mewujudkan Sumpah Palapa, menyatukan Nusantara memanfaatkan situasi yang tengah terjadi. Kedatangan rombongan itu, dipandang sebagai tanda takluk Kerajaan Sunda dan Dyah Pitaloka dipandang sebagai upeti. Prabu Linggabuana menolak tawaran Gajah Mada. Sebagai ksatria Sunda, ia lebih baik mati memertahankan kehormatan daripada takluk pada superioritas Majapahit.

Perang pun terjadi. Perang yang tidak seimbang antara prajurit Gajah Mada dan rombongan Raja Sunda mengakibatkan gugurnya Prabu Linggabuana dan rombongannya.

Peristiwa Perang Bubat pada abad ke-14 tersebut mendapat sambutan dan tanggapan masyarakat Sunda dan masyarakat Jawa berupa tulisan-tulisan, baik berupa kritik, artikel, dan karya sastra. Tulisan-tulisan yang berkaitan dengan Perang Bubat tersebut dapat dipandang sebagai respon masyarakat (pembaca) yang dalam istilah sastra disebut dengan resepsi sastra. Sambutan dan tanggapan terhadap Perang Bubat yang disebut resepsi sastra itu wujudnya, antara lain lahirnya penciptaan karya satra atas peristiwa Perang Bubat, kritik sastra, resensi, dan penelitian yang terbit dalam bentuk artikel jurnal.

Peristiwa Bubat pada abad ke-14 dan resepsi sastranya yang muncul beberapa abad kemudian menarik dibicarakan karena menggambarkan konfigurasi pendapat, tanggapan, kritik dan pandangan. Di antara tanggapan tersebut ada yang berpandangan bahwa perang itu terjadi karena ambisi Gajah
Mada, tetapi ada juga yang berpendapat bahwa dalam peristiwa tersebut Gajah Mada hanyalah korban.

Yang menjadi masalah dalam penelitian ini adalah bagaimana terjadinya peristiwa Perang Bubat dan bagaimana resepsi sastranya. Tujuan penelitian adalah menunjukkan latar belakang terjadinya Perang Bubat dan untuk mengungkapkan peristiwa Perang Bubat atas resepsi sastranya.

Penelitian terhadap pembaca, baik pembaca sejarah (dalam hal ini Perang Bubat) maupun pembaca karya sastra masih terbatas. Hal ini, antara lain karena peneliti terfokus pada teks yang terdapat dalam karya sastra. Padahal, peranan pembaca yang tidak mengetahui proses kreatif pengarang memegang peran penting.

Pembaca sebagai peresepsi atau penerima, yang menerima sebuah karya dapat menikmati, menilai, dan memanfaatkan pesan yang terkadung di dalam karya itu. Bahkan, dalam resepsi sastra, penulis atau pengarang yang mengetahui seluk-beluk karyanya tidak dipandang keberadaannya.

Penelitian "Perang Bubat pada Abad ke-14 dan Resepsi Sastranya" secara kepustakaan belum ada yang meneliti. Yang ada adalah penelitian tentang novelnovel Indonesia yang bertema Perang Bubat, kritik tentang Perang Bubat yang dipublikasikan dalam surat kabar, resensi tentang Perang Bubat dalam surat kabar. Hidayat (2015) meneliti "Pandangan Dunia Orang Sunda dalam Tiga Novel Indonesia tentang Perang Bubat". Kemudian, Asmalasari (2010) meneliti "Peristiwa Perang Bubat dalan Novel Perang Bubat Karya Yoseph Iskandar dan Novel Gajah Mada, Perang Bubat Karya Langit Kresna Hariadi (Kajian Sastra Bandingan)".

Sementara itu, tulisan tentang Perang Bubat yang lain didominasi oleh resensi, artikel dalam surat kabar, dan artikel dalam majalah. Sumarjo (2013) menulis artikel tentang "Sekitar Perang 
Bubat" dan Imran (2009) menulis artikel tentang "Perang Bubat yang Lain". Penelitian dan artikel dalam surat kabar serta majalah tersebut meneliti serta memberi ulasan atau kritik tentang peristiwa Perang Bubat yang terdapat dalam novel karya Yoseph Iskandar atau tentang Perang Bubat karya Langit Kresna Hariadi.

Sementara itu, penelitian ini mengkaji Perang Bubat dari sisi resepsi sastranya, yaitu melakukan penelitian terhadap karya-karya yang berupa penelitian, kritik, artikel, karya sastra, resensi yang berkaitan dengan Perang Bubat. Para penulisnya, dipandang sebagai peresepsi atau penerima Perang Bubat.

Penelitian resepsi sastra terhadap Perang Bubat dipandang penting sebagaimana diungkapkan oleh Wati (2013:3) bahwa penelitian resepsi sastra itu baru bermakna apabila suatu teks mempunyai hubungan dengan pembaca. Suatu teks membutuhkan adanya kesan yang tidak mungkin ada jika tidak ada pembacanya.

Jadi, jika suatu teks tidak ada pembacanya, teks tersebut tidak bermakna.

Abdullah (1991: 73) mengatakan bahwa resepsi sastra adalah aliran yang meneliti teks sastra dengan bertitik tolak pada pembaca yang memberi reaksi atau tanggapan terhadap teks. Pembaca selaku pemberi makna adalah variabel menurut ruang, waktu, dan sosial-budaya. Hal itu berarti bahwa karya sastra tidak sama pembacaan, pemahaman, dan penilaiannya sepanjang masa atau dalam seluruh golongan tertentu.

Menurut teori ini sambutan terhadap karya sastra diarahkan oleh "horizon harapan". Horizon harapan ini merupakan interaksi antara karya sastra dan pembaca secara aktif, sistem atau horizon harapan karya sastra di satu pihak dan sistem interpretasi dalam masyarakat penikmat di lain pihak. Horizon harapan karya sastra yang memungkinkan pembaca memberi makna terhadap karya tersebut sebenarnya telah diarahkan oleh penyair lewat sistem konvensi sastra yang dimanfaatkan dalam karyanya. Sastriyani (2001: mendeskripsikan bahwa teks memiliki "tempat-tempat terbuka" atau yang dikenal dengan istilah openness atau blank. Proses pembacaan adalah mengisi tempat-tempat terbuka tersebut. Ternpat terbuka tejadi karena sifat karya sastra yang asirnetris sehingga apabila pernbaca berhasil rnenjembatani kesenjangan tersebut komunikasi antara teks karya sastra dan pernbaca dapat dilakukan (Iser, 1980: 12).

Dalam kenyataan sejarah, tarnpak bahwa teks cenderung berubah dan tidak stabil wujudnya sepanjang masa (Teeuw, 1984: 250). Teks terbuka untuk mengalami perubahan. Perubahan yang diadakan dalam sebuah teks dapat dibedakan, perubahan rnungkin tejadi dalam hal transliterasi dan penggarapan kembali sebuah teks. Adakalanya teks diubah atas anjuran penerbit atau penyunting dengan alasan politik atau moralitas.

Sastriyani (2010) mengutip pendapat Chamamah bahwa penelitian resepsi dapat dilakukan dengan mempertimbangkan kedudukan peneliti yang berupa penelitian eksperimental, penelitian melalui kritik sastra, keberadaan struktur teks, dan proses penyalinan. Penelitian eksperimental menerapkan objek estetik yang bermacammacam, menetapkan perbedaan dan persamaan antara objek estetik, dan menetapkan relasi antarobjek estetik yang ditemukan dari artefak.

Penelitian yang didasarkan pada kritik yang ada tidak mengacu pada karya individual, tetapi tanggapan yang mewakili norma yang terikat pada masa tertentu dan waktu tertentu. Dalam penelitian ini, dapat diungkap apabila ada pertentangan dan ketegangan antara suatu pemakaian di luar konvensi dan suatu konvensi yang telah mapan dalam suatu masyarakat dengan inovasi yang dilakukan oleh pengarang. Penelitian resepsi dilihat dari fisik teks dapat berupa intekstual, penyalinan, penyaduran, dan penerjemahan (Charnamah, 2001: 162-163). 
Pradipta (2009: 13) menyitir pendapat Luxemburg (1989: 62) dan Nyoman Kutha Ratna (2007: 167) bahwa resepsi atau penerimaan dibedakan dengan penafsiran. Resensi novel di surat kabar termasuk penerimaan, sedangkan pembicaraan novel tersebut di majalah ilmiah termasuk penafsiran. Penerimaan pembaca akan menjadi sumber energi kreativitas. Dari konkretisasi yang dilakukan pembaca terhadap suatu karya sastra, akan lahir teks-teks baru yang bisa mencerminkan horizon harapan pembaca.

Dalam penelitian ini akan dibahas resepsi melalui kritik sastra, resepsi satra dalam bentuk penelitian, dan resepsi sastra melalui resensi.

\section{B. METODE PENELITIAN}

Penelitian yang dilakukan terhadap Perang Bubat pada Abad ke-14 dan Resepsi Sastranya menerapkan metode resepsi sastra. Di dalam metode ini, peran pembaca sangat menonjol, tetapi tetap dalam koridor pengarang dan karya sastra. Abdullah (1991: 75) mengutip pendapat Jauss (1992: 12-14) bahwa pembaca berperan aktif bahkan pembuat sejarah. Sejarah sastra adalah proses resepsi estetik dan produksi yang bertempat dalam realisasi teks sastra sebagai bagian dari resepsi sastra, refleksi kritikus, dan pengarang dalam kesinambungan kreativitasnya.

Metode resepsi sastra mendasarkan diri pada teori bahwa karya sastra sejak terbit selalu mendapat tanggapan dari pembacanya. Menurut Jauss, apresiasi pertama pembaca terhadap karya sastra akan dilanjutkan dan diperkaya melalui tanggapan-tanggapan lebih lanjut dari generasi ke generasi.

Tugas resepsi estetik berkenaan dengan interpretasi adalah meneliti konkretisasi pembaca terhadap sebuah teks sastra. Pakar yang mengetahui kemungkinan konkretisasi akan mampu memberikan interpretasi yang lebih masuk akal, apalagi jika konkretisasi itu diberikan oleh pembaca-pembaca canggih.
Konkretisasi yang tidak didasarkan pada struktur teks dan struktur sistem nilai tidak relevan.

Penerapan metode penelitian resepsi sastra bertolak dari uraian di atas dapat dirumuskan ke dalam tiga pendekatan, yakni (1) pendekatan resepsi sastra secara eksperimental, (2) penelitian resepsi sastra lewat kritik sastra, dan (3) penelitian resepsi intertekstualitas.

Dalam penelitian ini digunakan cara yang kedua, yaitu penelitian resepsi satra lewat kritik sastra. Langkah penelitian ini dilakukan dengan dua cara. Pertama, secara sinkronik dan kedua, secara diakronik. Secara sinkronik maksudnya meneliti resepsi sastra dalam satu masa atau satu periode sehingga akan menggambarkan horizon harapan pada masa itu. Lalu, secara diakronik dapat meneliti resepsi sastra terhadap suatu karya sepanjang perjalanan sejarahnya.

Penelitian ini menerapkan resespsi sastra secara diakronik atau sepanjang masa. Peristiwa Perang Bubat terjadi pada abad ke-14. Resepsi sastra tentang perang Bubat muncul pada abad ke-16 dan pada abad-abad berikutnya. Resepsi sastra terhadap Perang Bubat pada abad ke-16 dan abad-abad berikutnya inilah yang akan menjadi pengamatan.

Pengumpulan data dilakukan dengan cara melacak data resepsi sastra atau tanggapan pembaca terhadap Perang Bubat setelah abad ke-14. Sumber tua yang menceritakan adanya peristiwa Perang Bubat pada abad ke-16 adalah Kidung Sunda dan Pararaton yang berbahasa Jawa kuno dan Carita Parahiyangan yang berbahasa Sunda kuno. Akhir-akhir ini muncul naskah Pangeran Wangsakerta dari Cirebon yang berbahasa Jawa yang juga menyambut adanya peristiwa Bubat.

Kidung Sunda yang menjadi data penelitian ini berupa terjemahan Hasan Wirasutisna terbitan 1980. Kemudian, Carita Parahyangan yang disalin pada abad ke-16 atau awal abad ke-17 yang disusun oleh Noorduyn tahun 1962. Carita Purwaka Caruban Nagari karya Pangeran 
Arya yang ditulis tahun 1720 dan diterbitkan tahun 1972. Buku Sejarah Jawa Barat karya Saleh Danasasmita, dkk. diterbitkan oleh Pemda Jabar tahun 1984.

Pengumpulan data tersebut menghasilkan data yang cukup beragam, antara lain berupa buku, artikel jurnal, kritik sastra dan resensi dalam surat kabar dan majalah, dan karya sastra Indonesia modern.

Data yang terkumpul diklasifikasi berdasarkan jenis tanggapan. Kemudian, dianalisis substansinya. Penganalisisan data dilakukan terhadap tanggapantanggapan. Analisis resepsi sastra terhadap Perang Bubat itu diarahkan pada substansi dan horizon harapan si peresepsi.

Analisis resepsi pembaca terhadap Perang Bubat akan memperlihatkan makna peristiwa Perang Bubat secara lengkap.

\section{HASIL DAN BAHASAN}

\section{Perang Bubat dan Resepsi Sastranya}

Perang Bubat mengundang berbagai tanggapan dan reaksi masyarakat terutama setelah peristiwa itu diceritakan atau dicatat dalam buku yang berbahasa Sunda dan Jawa. Resepsi masyarakat terhadap muncul abad ke-16 sampai dengan abad ke- 21. Secara umum resepsi sastra dari abad ke abad nyaris menanggapi kepahlawan Raja Sunda, keberanian Putri Dyah Pitaloka, kebesaran Kerajaan Majapahit, dan kekuatan Patih Gajah Mada.

Resepsi sastra terhadap Perang Bubat tersebut berupa penceritaan kembali, komentar dan tanggapan tentang sejarah Sunda, karya sastra, penilaian atau resensi, dan kritik sastra. Tanggapan terhadap Perang Bubat tercatat pada abad ke-16, abad ke-17, abad 19, dan muncul kembali abad ke-20.

Resepsi sastra terhadap Perang Bubat secara substansi sangat bergantung pada horizon harapan pembacanya saat tanggapan itu dikemukakan, misalnya resepsi sastra dari Hasan Wirasutisna pada abad ke-16, resepsi sastra dari Pangeran Wangsakerta abad ke-18, dan resepsi sastra dari Yosep Iskandar pada abad ke20 akan menunjukkan persamaan dan perbedaan. Persamaan dan perbedaan tersebut karena horizon harapan pembaca tidak sama. Di samping itu, ruang dan waktu akan menentukan hasil peresepsian.

Dengan demikian, resepsi sastra terhadap Perang Bubat akan cukup beragam mengingat horizon harapan masyarakat datang dari berbagai kalangan.

Berkaitan dengan sejarah, dipertanyakan apakah Perang Bubat itu pernah terjadi atau hanya rekaan?

Sumarjo (2013: 1) menerima Perang Bubat sebagai peristiwa sejarah karena ada tiga sumber tua yang menceritakan adanya peristiwa tersebut, yaitu Kidung Sunda, Pararaton yang berbahasa Jawa kuno, dan Parahiyangan yang berbahasa Sunda kuno. Akhir-akhir ini muncul naskah Pangeran Wangsakarta dari Cirebon yang berbahasa Jawa. Menilik sumber tua yang berasal dari dua masyarakat yang terlibat dalam Perang Bubat (Sunda dan Majapahit) kemungkinan besar tidak saling berhubungan, dapat ditafsirkan bahwa Perang Bubat adalah peristiwa sejarah.

Sumber tertulis tersebut berasal dari abad ke-16, sedangkan Perang Bubat terjadi pada abad ke-14. Jadi, terdapat selisih dua abad antara peristiwa itu terjadi dan tuturannya. Meskipun demikian, ingatan kolektif masyarakat pada peristiwa tersebut masih cukup kuat yang kemudian tertuang dalam tradisi sastra kedua masyarakat.

Ekajati dalam Hidayat (2015: 103) berpendapat bahwa Perang Bubat adalah peristiwa sejarah yang pernah terjadi pada abad ke-14 yang melibatkan Kerajaan Sunda dan Kerajaan Majapahit. Disebut peristiwa sejarah karena Perang Bubat tercatat dalam beberapa sumber tradisional historiografi Nusantara seperti dalam kitab Pararaton, Kidung Sunda, Kidung Sundayana, dan Carita Parahiyangan.

Sementara itu, Anugrah (2015: 3) menyitir pendapat Aminuddin Kasdi, sejarawan Universitas Negeri Surabaya, 
bahwa sebagai sumber sejarah, Kidung Sunda, merupakan sumber sekunder, bahkan tersier. Berbagai fakta sejarah di dalamnya tidak sesuai dengan sumbersumber lain yang lebih kredibel seperti prasasti. Perlu diperhatikan pula bahwa pada abad ke-19, kurun waktu penulisan Kidung Sunda, merupakan masa munculnya beberapa karya sastra kontroversial.

Edi Sedyawati dalam (Anugrah, 2015: 4) bahkan menyoroti peran Pemerintah Kolonial dalam memperkenalkan Peristiwa Bubat kepada khalayak. "Oleh Pemerintah Belanda, Kidung Sunda dijadikan bahan ajar bagi siswa di Algemeene Middelbare School (AMS). Mengapa tidak menggunakan karya sastra yang lebih dikenal seperti Ramayana dan Bharatayudha. Ada kepentingan Belanda di dalamnya," ujar Sedyawati, mengaitkan terbitnya teks-teks Sunda yang dekat dengan peristiwa Sumpah Pemuda. Pasundan-Bubat menjadi misteri yang butuh dipecahkan. Karena peristiwa itu tertanam dalam ingatan kolektif masyarakat.

Beberapa pendapat tersebut mengimplikasikan adanya kontroversi tentang peristiwa Perang Bubat, yaitu antara peristiwa sejarah yang benar terjadi dan suatu rekayasa demi kepentingan politik.

Terlepas dari itu, Perang Bubat yang terjadi pada abad ke-14 telah meramaikan jagat sastra Sunda dan Indonesia.

\section{Resepsi Sastra Berupa Pengaruh terhadap Lahirnya Karya Baru}

Peristiwa Perang Bubat pada abad ke-14 mendapatkan tanggapan dan sambutan dari masyarakat. Masyarakat merespon peristiwa tersebut melalui karyakarya sastra.

Karya sastra daerah adalah Carita Parahyangan, Kidung Sunda, Pararaton, Carita Purwaka Caruban Nagari. Kemudian, karya sastra Indonesia modern, yakni Sang Mokteng Bubat (1991) karya
Yoseph Iskandar, Dyah Pitaloka: Senja di langit Majapahit (2005) karya Hermawan Aksan, Perang Bubat: Tragedi di Balik Kisah Cinta Gajah Mada dan Dyah Pitaloka (2009) karya Aan Merdeka Permana, Gajah Mada, Perang Bubat (2006) karya Langit Kresna Hariadi.

Hadirnya karya sastra yang bertema Perang Bubat, dapat dipandang sebagai bentuk resepsi sastra yang mengimplikasikan bahwa Perang Bubat mendapat perhatian tidak saja oleh masyarakat sezaman, tetapi menembus zaman hingga masyarakat modern.

Kidung Sunda ditampilkan dalam bentuk puisi yang ditembangkan. Peresepsi Kidung Sunda mendeskripsikan Raja Hayam Wuruk yang masih muda mengutus patih muda melamar putri Maharaja di Galuh setelah melihat gambar putri dalam lukisan karya Arya Prabangkara. Maharaja Sunda bersyukur kepada Yang Maha Kuasa karena mendapat anugerah, putrinya diambil sebagai permaisuri Raja Agung Majapahit yang menguasai tujuh raja di Pulau Jawa. Raja Galuh memimpin rombongan pengantin perempuan menuju Majapahit.

Galuh termenung memandang raut berwarna merah darah dan gagak melayang-layang di udara meneteskan darah ke laut. Raja Galuh menangkap gelagat buruk bakal datangnya malapetaka. Raja Galuh pasrah, kalaupun hal itu terjadi, ia menerimanya sebagai takdir. Memasuki pedalaman dari pelabuhan Ujung Galuh menyusuri sungai dan sampailah di Bubat menunggu jemputan Raja Hayam Wuruk. Raja dan yang lain gembira Raja Sunda tiba dengan selamat, tetapi Patih Gajah Mada kecut karena tidak menyetujui kehendak Raja beristri Putri Galuh. Ia usul kepada Raja agar menunda pertemuan dengan Raja Sunda dengan pertimbangan wibawa dan keagungan raja serta Kerajaan Majapahit akan turun di mata raja-raja Pulau Jawa dan Nusantara. Kata-kata Gajah Mada memengaruhi sikap Hayam Wuruk. 
Desas-desus tersebut terdengar oleh Raja Galuh. Ia mengutus para patihnya ke istana Hayam Wuruk. Di Gerbang istana, mereka melihat Gajah Mada sedang rapat dengan petinggi negara. Gajah Mada mengabaikannya meskipun ia melihat ke arah rombongan. Gajah Mada menegur utusan Raja Sunda sebagai orang tidak paham tata krama. Terjadilah perdebatan sengit. Gajah Mada menyindir Raja Sunda yang datang tidak membawa persembahan. Utusan Raja Sunda tidak menerima tuduhan itu. Karena Gajah Mada meminta Putri Galuh sebagai persembahan, sedangkan Raja Sunda menolak keinginan itu maka terjadilah perang.

Kisah yang disajikan dalam Kidung Sunda dapat ditafsirkan bahwa terjadinya Perang Bubat karena pengkhianatan Gajah Mada. Horizon harapan peresepsi Kidung Sunda menjunjung nilai-nilai sebuah harga diri dan martabat seorang raja dan putri raja yang lebih baik mati berkalang tanah daripada selamat, tetapi tidak membanggakan rakyat dan negaranya. Peresepsi Kidung Sunda juga meyakini adanya suatu firasat buruk yang akan menimpa rombongan jika ada yang melihat tanda-tanda merah, darah, gagak yang dalam perjalanan sudah tampak. Namun, hal itu tidak diterima secara marah, panik, dan gusar. Tanda-tanda alam yang diyakini sebagai kearifan lokal.

Carita Parahyangan meresepsi terjadinya Perang Bubat sebagai ulah Patih Gajah Mada. Anugrah (2015: 2) menyatakan bahwa pada abad ke-20, Berg, sejarawan Belanda, menerbitkan teks dan terjemahan Kidung Sunda pada tahun 1927 yang mengurai peristiwa Bubat dalam versi yang lebih pendek. Berg menyebut Kidung Sunda mengandung fakta sejarah.

Beberapa abad kemudian, tepatnya tahun 1972, Pangeran Arya meresensi Perang Bubat dengan melakukan penulisan Purwaka Caruban Nagari yang bersumber pada naskah yang lebih tua, yaitu Negara Kertabumi (1677) karya Pangeran
Wangsakerta. Oleh karena itu naskah tersebut disebut dengan naskah Wangsakerta. Wangsakerta dipandang masih berharga untuk mengetahui tentang Perang Bubat. Wangsakerta menurut Sumarjo (2013: 15) menambah informasi bahwa Raja Majapahit, Hayam Wuruk meminta maaf kepada Prabu Maharaja Sunda atas peristiwa Perang Bubat.

Kemudian, dilakukan rekonsiliasi kedua kerajaan. Kidung Sunda, Pararaton, dan Carita Parahyangan tidak menyebutkan kelanjutan kisah setelah terjadinya Perang Bubat. Jadi, hanya naskah Wangsakerta yang menggambarkan beberapa peristiwa yang berbeda dengan karya-karya itu, seperti menunjuk biang kesalahan pada Patih Gajah Mada. Perbedaan dan persamaan tanggapan tersebut menunjukkan bahwa horizon harapan si peresepsi tidak sama. Peresepsian yang tidak sama menambah wawasan masyarakat yang ingin mengetahui tentang Perang Bubat.

Tanggapan masyarakat yang berkaitan dengan Perang Bubat terdapat pula dalam Pararaton, sebuah naskah kuno yang berasal dari Jawa Timur.

Secara garis besar horizon harapan yang tertuang di dalam kitab ini tidak jauh berbeda dengan Kidung Sunda dan Carita Parahyangan. Hanya di bagian akhir terdapat pernyataan bahwa... "Menikmati masa istirahat menjadi Mangkubumi selama 11 tahun di Majapahit". Implikaisnya adalah Gajah Mada selama menjadi Patih yang dalam Pararaton disebut Mangkubumi dipandang berhasil menaklukkan raja-raja Jawa dan menyatukan Nusantara dan Perang Bubat merupakan usaha terakhir Gajah Mada membawa Kerajaan Galuh berada di bawah naungan Majapahit. Jadi, dalam Kitab Pararaton, Gajah Mada yang dijuluki Mangkubumi dipandang sebagai pahlawan.

Seiring waktu dan perubahan zaman muncul resepsi masyarakat terhadap Perang Bubat dalam bentuk sastra modern seperti novel. 
Lahirnya novel Indonesia modern yang bersumber pada peristiwa Perang Bubat merupakan penerimaan atau respon masyarakat terhadap Perang Bubat dari generasi yang lebih kemudian atau dapat dikatakan pandangan dan tanggapan pembaca yang paling mutakhir. Resepsi sastra atas novel-novel tersebut dapat diketahui dalam bagian 3.1.

\section{Resepsi Sastra Berupa Unsur Karya}

Setelah data diklasifikasi terdapat resepsi sastra terhadap novel Indonesia modern yang menanggapi unsur pembentuk struktur, seperti tokoh, alur, dan latar.

Peresepsian sastra yang membandingkan unsur struktur novel, yaitu antara novel Perang Bubat Karya Yoseph Iskandar dan novel Gajah Mada, Perang Bubat karya Langit Kresna Hariadi. Asmalasari (2010: 107)) meresepsi dua novel tersebut dengan membandingkan tokoh dalam Perang Bubat karya Yoseph Iskandar dengan tokoh dalam novel Gajah Mada, Perang Bubat karya Langit Kresna Hariadi. Tokoh yang dibandingkan adalah Hayam Wuruk, Raja Sunda, Dyah Pitaloka, dan Gajah Mada.

Perbandingan tokoh dalam dua novel tersebut ditanggapi dari sudut pandang pengarang dengan memerhatikan latar belakang pengarangnya.

Adanya tanggapan bahwa latar belakang pengarang dan kultur etnik yang berbeda, yaitu Sunda dan Jawa akan menghasilkan sudut pandang yang berbeda. Asmalasari menyoroti persamaan dan perbedaan sudut pandang dua pengarang tersebut melalui aspek rencana pernikahan, pengkhianatan, dan ambisi.

Dalam rencana pernikahan, novel Perang Bubat dan Gajah Mada, Perang Bubat memiliki persamaan, yaitu samasama menceritakan keinginan Hayam Wuruk menikahi Dyah Pitaloka karena Raja Majapahit itu terpikat oleh kecantikannya. Tujuan lain rencana pernikahan itu untuk mempererat tali persaudaraan antara Majapahit dan Sunda. Perbedaannya adalah ketika rombongan Dyah Pitaloka tiba di Bubat, dalam novel Perang Bubat, Hayam Wuruk tidak hadir dalam penjemputan rombongan karena dilarang oleh Gajah Mada, tetapi dalam novel Gajah Mada, Perang Bubat, Hayam Wuruk tidak hadir dalam rombongan penjemputan karena direkayasa oleh Lurah Arya Sentong.

Kemudian, dalam aspek pengkhianatan yang menceritakan terjadinya Perang Bubat adalah kedua novel memiliki persamaan, yaitu terjadinya Perang Bubat yang menyebabkan gugurnya rombongan Sunda karena pengkhianatan. Pengkhianatan itu terletak pada anggapan bahwa kedatangan rombongan Sunda ke Bubat dipandang sebagai tanda takluk dan mengakui kekuasaan Majapahit. Hal itu ditolak oleh Raja Sunda. Perbedaannya, dalam novel Perang Bubat, Hayam Wuruk mengetahui siasat Gajah Mada yang menjadikan Dyah Pitaloka sebagai putri persembahan. Hayam Wuruk berada di bawah kendali patihnya. Gajah Madalah yang mengatur pemerintahan. Gajah Mada memegang hak atas sabda pandita ratu, yang diperintahkannya harus terwujud .

Hayam Wuruk dalam novel Gajah Mada, Perang Bubat tidak mengetahui apa pun tentang rencana Dyah Pitaloka dijadikan upeti. Oleh karena itu, ia tetap menjalankan berbagai ritual prapernikahan. Dalam aspek Ambisi, Gajah Mada berambisi ingin menyatukan Nusantara di bawah panji-panji Majapahit. Kedua novel tersebut sama-sama memiliki ambisi Gajah Mada. Saat itu, hampir seluruh wilayah Nusantara bersatu kecuali Sunda. Gajah Mada sangat ingin menaklukkan Sunda. Momen Bubat dijadikan jalan untuk mewujudkan cita-citanya.

Perbedaan kedua novel tersebut adalah dalam novel Perang Bubat, Gajah Mada adalah "dalang" terjadinya Perang Bubat. Pernikahan Hayam Wuruk dan Dyah Pitaloka dimanfaatkan untuk 
menaklukkan Sunda, sedangkan dalam novel Gajah Mada, Perang Bubat, tokoh Gajah Mada digambarkan sebagai korban. Ia diperalat oleh sebagian pendukungnya yang tidak menginginkan adanya pernikahan itu.

Adanya persamaan dalam novel tersebut dapat diinterpretasikan bahwa kedua pengarang, yaitu Yosep Iskandar dan Langit Hariadi Kresna dalam proses kreatifnya mengacu pada sumber yang sama, yaitu peristiwa Perang Bubat, sedangkan terjadinya perbedaan penerimaan yang berkaitan dengan tokohtokoh dalam novel menunjukkan bahwa selain horizon harapan terhadap Perang Bubat yang tidak sama juga latar belakang kultur pengarang cukup memengaruhi pencitraan tokoh.

Hariadi sebagai orang Jawa mencitrakan Gajah Mada sebagai protagonis yang menjadi korban sehingga nama baiknya tetap terjaga, sedangkan Yoseph Iskandar sebagai orang Sunda memandang Gajah Mada sebagai penyebab terjadinya peristiwa Perang Bubat.

Peresepsi sastra lain yang menanggapi dan menyambut novel yang bertema Perang Bubat secara stuktural adalah hasil penelitian Hidayat. Hidayat (2015: 117) secara khusus menanggapi pandangan tokoh dalam tiga novel tentang Perang Bubat, yaitu dalam Sang Mokteng Bubat (1991) karya Yoseph Iskandar, Dyah Pitaloka: Senja di langit Majapahit (2005) karya Hermawan Aksan, dan Perang Bubat: Tragedi di Balik Kisah Cinta Gajah Mada dan Dyah Pitaloka (2009) karya Aan Merdeka Permana.

Hasil analisis terhadap pandangan tokoh dalam menghadapi berbagai masalah yang dihadapinya dipandang sebagai pandangan dunia orang Sunda. Pandangan dunia orang Sunda dalam tiga novel tersebut adalah (1) pandangan dunia tentang kepemimpinan dan harga diri, (2) pandangan dunia tentang perempuan, dan (3) pandangan dunia tentang arti cinta, kepasrahan, dan kebahagiaan.
Pandangan dunia tentang
kepemimpinan dan harga diri terdapat pada novel Sang Mokteng Bubat. Tokoh yang dijadikan acuan untuk mengidentifikasi pandangan dunia adalah tokoh utama. Dalam novel itu, tokoh utama adalah sang Prabu. Ketika sang Prabu menghadapi masalah di Palagan Bubat, yaitu ia dihadapkan pada dua pilihan yang harus segera diputuskan: menerima atau menolak usulan tokoh Mahapatih Gajah Mada agar tunduk pada Kerajaan Majapahit. Jika menerima, sang Prabu menjadi hina karena itu mengimplikasikan tunduk kepada Raja Majapahit, jika menolak berarti harus perang melawan prajurit Majapahit. Putusan yang diambil sang Prabu adalah memertahankan harga diri sebagai raja dan orang Sunda.

Dipandang dari resepsi pembaca, Hidayat menerima Sang Mokteng Bubat sebagai pandangan dunia orang Sunda yang berkaitan dengan jati diri orang Sunda yang lebih suka memertahankan harga diri daripada tunduk atau berada di bawah kekuasaan orang lain.

Pandangan dunia nomor 2, yaitu pandangan dunia tentang perempuan yang teresepsikan melalui novel Dyah Pitaloka. Protagonis novel, Dyah Pitaloka adalah perempuan Sunda yang bertekad mengangkat derajat perempuan Sunda agar sejajar dengan pria. Citra perempuan Sunda yang dicita-citakannya tidak lagi seperti Dayang Sumbi atau Purbasari, tetapi seorang perempuan yang cakap, pintar, dan ngelmu 'ilmu olah tubuh'.

Dyah Pitaloka berjuang memertahankan kehormatan negerinya sampai titik darah penghabisan.

Pendirian dan pandangan Dyah Pitaloka dipandang sebagai pandangan dunia orang Sunda yang berkaitan dengan perempuan. Perempuan Sunda harus menjaga kehormatan negerinya sebagai yang utama, sedangkan urusan pribadi harus menjadi nomor dua.

Pandangan dunia nomor 3 adalah tentang arti cinta, kepasrahan, dan kebahagiaan yang teresepsikan dalam 
novel Perang Bubat: Tragedi di Balik Kisah Cinta Gajah Mada dan Dyah Pitaloka.

Protagonis novel, yaitu Dyah Pitaloka berpandangan bahwa sebagai perempuan apalagi perempuan putri raja, harus menerima apapun yang menimpa pada dirinya dan harus pasrah. Sementara itu, Gajah Mada Muda atau Ramada berkelana mencari kebahagiaan sampai ke Tanah Sunda. Ketika "menjalin cinta" dengan Dyah Pitaloka, Ramada menemukan kebahagiaan.

Namun, kebahagiaan itu tidak abadi. Sang Prabu, ayahanda Dyah Pitaloka, tidak berkenan menerima Gajah Mada sebagai menantu karena alasan kelas. Gajah Mada meneruskan perjalanan sampai ke Majapahit. Di sinilah, ia meniti karier sampai mencapai patih. Patih Gajah Mada menemukan kebahagiaan setelah berhasil menyatukan Nusantara dengan sumpahnya yang termasyur, Sumpah Palapa.

Hermawan Aksan meresepsi peristiwa Perang Bubat sangat berbeda dengan novel-novel lainnya. Ia menggambarkan hubungan asmara antara Dyah Pitaloka dan Gajah Mada sebelum Gajah Mada menjadi Patih Majapahit. Jadi, dalam novel ini sesungguhnya Gajah Mada sudah mengenal Dyah Pitaloka ketika Rombongan Raja Sunda mendatangi Kerajaan Majapahit. Gajah Mada tidak rela kekasihnya akan diperistri Raja Hayam Wuruk. Hal ini antara lain yang menjadi latar belakang terjadinya Perang Bubat.

Kemudian, Sulwesi (2006: 1-3) meresensi novel Senja di Langit Majapahit karya Hermawan Aksan. Secara khusus Sulwesi meresensi tokoh Gajah Mada dan Dyah Pitaloka. Ia menggambarkan Gajah Mada dengan penokohan yang memiliki dua sisi, yaitu sisi baik dan sisi buruk. Sisi baiknya, Gajah Mada adalah seorang patih yang setia. Kesetiaannya kepada kerajaan tidak perlu diragukan. Hidupnya pun dibaktikan demi kejayaan Majapahit. Sisi buruknya, Gajah Mada adalah tokoh yang ambisius, licik, dan keji.
Yang menjadi tokoh sentral adalah Dyah Pitaloka. Ia digambarkan sebagai putri Linggabuawana yang cantik, cerdas, dan baik hati. Setelah menerima lamaran Raja Hayam Wuruk, Dyah Pitaloka pergi bersama rombongan Kerajaan Sunda menyongsong masa depan ke Tanah Jawa.

Masa depan yang disambutnya di luar dugaannya, Ia tidak sekadar menyerahkan diri, tetapi mengantar nyawanya. Putri Sunda itu tewas dengan gagah berani di ujung tusuk konde. Ia memilih mati bersama ayahanda dan rakyatnya demi membela kehormatan negeri daripada takluk.

Penokohan novel ini dinilainya juga sebagai sesuatu yang berlebihan terutama saat menggambarkan Hayam Wuruk sebagai Raja Majapahit yang gagah, tetapi menangis meratapi kematian Dyah Pitaloka, calon permaisuri yang tewas di medan laga.

Sulwesi sebagai penerima dan pembaca novel Senja di Langit Majapahit karya Hermawan Aksan juga menyoroti aspek alur cerita yang diterimanya adanya pengembangan alur. Pengembangan alur dalam novel ini dipandang sebagai sesuatu yang menarik. Menurutnya, pengembangan alur tampak dari upaya pengarang yang leluasa menggabungkan antara fakta dan imajinasi. Fakta diperoleh dari peristiwa Perang Bubat, sedangkan fiksi sebagai imajinasi dan kreativitas pengarang.

Peresepsi sastra lain adalah Satria (2008:1) menyoroti tokoh Dyah Pitaloka yang tidak menyerah pada keingingan Gajah Mada supaya takluk pada Raja Hayam Wuruk, sebagai upeti. Namun, Satria menyayangkan perempuan ini bunuh diri. Menurut Satria, Dyah Pitaloka seharusnya tidak bunuh diri. Ia harus tetap tegar dan meneruskan perjuangan ayahnya yang membela negara sampai titik darah penghabisan.

Di sisi lain, Satria juga meresepsi asal-muasal terjadinya Perang Bubat. Penulis artikel ini membuat semacam sinopsis yang isinya mengungkapkan latar 
belakang terjadinya perang. Analisis Satia diawali dengan ketertarikan Hayam Wuruk kepada putri Sunda Galuh yang bernama Dyah Pitaloka.

Namun, ketika antarkeluarga sudah saling menyetujui, Mahapatih Gajah Mada memiliki pemikiran lain. Ia memandang bahwa Sunda Galuh harus takluk kepada Kerajaan Majapahit dan Dyah Pitaloka dianggap putri seserahan. Putri itu bukan calon istri yang sederajat dengan Raja Hayam Wuruk.

Dalam kaitannya dengan penerimaan pembaca, penulis artikel ini mempertanyakan mengapa tokoh Dyah Pitaloka sampai bunuh diri? Untuk menjawab pertanyaan itu agak sulit karena tidak ada sumber sejarah yang menerangkan secara detail apa motivasi Dyah Pitaloka bunuh diri. Pemahaman umum yang berkembang adalah karena semua keluarga tewas di medan laga, Dyah Pitaloka putus asa lalu bunuh diri.

Satria juga menilai Langit Krisna Hariadi termasuk pengarang kreatif yang memanfaatkan peristiwa Perang Bubat sebagai novel yang di dalamnya mengandung kisah cinta romantik dengan akhir yang tragis. Ia menampilkan kisah hidup Dyah Pitaloka yang sebenarnya sudah terlanjur jatuh cinta kepada seorang rakyat jelata yang bernama Saniscara.

Saniscara adalah seorang pemuda yang pandai melukis. Ia selalu mencurahkan rasa cintanya pada Dyah Pitaloka melalui lukisan. Lukisan yang mengabadikan Dyah Pitaloka inillah yang akhirnya sampai ke tangan Hayam Wuruk.

Kisah cinta Dyah Pitaloka dengan Saniscara gagal di tengah jalan. Dyah Pitaloka dan Saniscara tidak mungkin sampai ke pernikahan karena faktor politik dan status sosial yang berbeda.

Hal ini memberikan ruang bagi pembaca untuk bereksplorasi tentang apakah sesungguhnya cinta harus dihalangi oleh norma-norma seperti politik dan status sosial?

Pembaca lain yang juga menanggapi peristiwa Perang Bubat adalah Raksa.
Raksa (2012) secara khusus meresepsi buku Kidung Sunda dengan judul "Analisa Kidung Sunda". Ia membahas isi Kidung Sunda dengan detail. Bahasan Raksa lebih tepatnya berupa kritik.

Hal pertama yang dikritik oleh Raksa (2012: 1) adalah jumlah armada dan rombongan Raja Galuh ketika berkunjung ke Kerajaan Majapahit. Armada kapal kecil berjumlah 200 dan sejumlah kapal berukuran besar. Hitungan matematis sederhana menurut Raksa jumlah itu mengimplikasikan bahwa satu perahu ratarata membawa 10 orang, berarti rombongan berjumlah 20.000 orang. Itu bukan jumlah sedikit. Boleh dikatakan 20.000 orang adalah jumlah yang berlebihan untuk sebuah acara pernikahan.

Jumlah orang sebanyak itu cukup untuk sebuah rencana penggempuran atau penyerangan suatu negara atau kerajaan lain pada saat itu.

Jika rencana penyerangan terhadap kerajaan lain itu benar, yang menjadi pertanyaan adalah mengapa istri dan putri Raja Galuh ikut dalam perjalanan itu?

Raksa menerimanya sebagai sesuatu yang biasa atau lumrah. Keikutsertaan istri dan putri raja dalam perjalanan pertempuran hal yang wajar seperti yang dilakukan oleh pasukan Mongol-yang melakukan perjalanan panjang ke negara lain sering membawa keluarga--. Mereka membawa keluarga sekaligus memanfaatkannya untuk persiapan upacara sebelum memulai perang. Keluarga juga dalam perjalanan panjang dapat menjadi motivator, menambah semangat tempur bagi raja dan pasukan.

Interpretasi bahwa Raja Galuh berangkat ke Bubat akan perang diperkuat oleh sebuah pernyataan dalam Kidung Sunda:

"Orang Sunda akan mempersembahkan putri raja, tetapi tidak diperkenankan oleh bangsawan-bangsawannya. Mereka sanggup gugur di medan perang, tidak akan menyerah, akan mempertaruhkan darahnya." 
Pernyataan tersebut memberikan informasi adanya pemberitahuan dari Raja Sunda Galuh kepada para bangsawannya tentang penyerahan putri raja sebagai persembahan bagi Raja Majapahit

Para bangsawan menolak pilihan itu. Artinya, teori rencana penyerahan sang putri yang akan dinikahkan dengan Raja Hayam Wuruk tidak pernah terjadi. Yang ada Raja Sunda Galuh dan pembesar istana sepakat menyatakan perang terhadap Majapahit.

Simpulannya, Perang Bubat ini sudah direncanakan sebelumnya. Daerah Bubat sengaja dipilih karena lokasi ini dipandang sebagai daerah strategis yang sudah ditetapkan untuk menggepur Kerajaan Majapahit

Perumpamaan yang lain menurut teori Raksa adalah perjalanan berlayar dari tanah Sunda ke tanah Jawa ujung timur dipastikan menggunakan perahu yang memuat jumlah personil lebih dari tiga puluh orang dalam satu perahu. Jika dijumlahkan dari rata-rata satu buah, total jumlah orang mencapai 60.000 orang. Jumlah yang fantastis untuk sebuah rencana penyerangan sekaligus membumihanguskan Kerajaan Majapahit yang sedang melakukan invansi ke luar wilayah kerajaan.

Raksa memberi dua kemungkinan tentang perahu yang digunakan rombongan Sunda Galuh. Perahu itu produksi rakyat Sunda Galuh dengan teknologi pada masa itu yang sangat dimungkinkan atau bisa jadi hasil membeli dari negara lain karena perahu yang digunakan adalah perahu besar yang mirip dengan perahu tentara Mongol waktu menyerang Kerajaan Kediri pada masa pemerintahan Jayakatwang.

Raksa menduga perahu dibeli dari Kerajaan Sriwijaya karena kerajaan itu terkenal mempunyai teknologi maritim yang unggul. Selain itu, sesuatu yang wajar jika kapal yang digunakan merupakan kapal megah yang sangat luar biasa karena Kerajaan Sunda Galuh hidup makmur dan besar wilayah kekuasaannya ingin menunjukkan superioritas perekonomian dan kemampuan dana yang besar.

Kemudian, Raksa (2012: 4) juga tidak menerima isi Kidung Sunda yang di dalamnya mendeskripsikan perjalanan Raja Sunda Galuh menuju Kerajaan Majapahit untuk menemui Raja Hayam Wuruk.

Menurut Raksa, tradisi Jawa atau Sunda, dan di mana pun dalam pernikahan, laki-laki pihak laki-laki yang harus datang ke tempat calon istri. Ini sebaliknya. Jika Raja Sunda Galuh dan pasukannya yang digambarkan dalam Kidung Sunda dikatakan merasa terhina sebagai alasan untuk berperang pada saat itu karena dminta takluk secara miliiter oleh Gajah Mada, secara logika itu tidak mungkin. Jika alasan perang seperti itu, sebenarnya sejak awal dia sudah menghinakan diri dengan datang mengantar Putri Citraresmi sebagai calon istri Raja Majapahit, Hayam Wuruk.

Jadi, hal ini merupakan paradoks yang tidak dapat diterima. Jika memang di daerah tertentu terdapat pihak perempuan mendatangi pihak laki-laki dalam kaitannya dengan pernikahan, itu merupakan kebenaran yang tidak dapat diterima.

Kemudian, Raksa (2012: 8) mengungkapan satu nilai yang paling menonjol dalam Kidung Sunda, yaitu nilai kepahlawanan. Nilai ini tampak dari pasukan Sunda Galuh. Kepahlawanan pasukan Sunda Galuh tidak mengenal kata menyerah. Mereka perang seperti model perang puputan, yaitu perang sampai habis-habisan. Mereka memiliki semangat perang sampai titik darah terakhir. Mereka gugur sebagai pahlawan perang.

Nilai kepahlawan ini sangat membanggakan dan mengharukan bagi siapa pun yang membacanya. Di sini pun digambarkan pihak lawan, yaitu pasukan Kerajaan Majapahit merasa terharu kepada pasukan Sunda Galuh. Untuk itu, pasukan Kerajaan Majapahit memberi penghormatan pada pasukan yang gugur. 
Hal terakhir yang diresepsi oleh Raksa (2012: 12) adalah perihal kekalahan pasukan Sunda Galuh. Raksa menginterpretasi kekalahan tersebut disebabkan pasukan Sunda Galuh tidak terlatih dalam perang, sedangkan pasukan Kerajaan Majapahit yang sedang menginvasi negara lain sering perang. Bahkan dalam Kidung Sunda dinyatakan bahwa Gajah Mada mempunyai pasukan elit intelejen yang bernama Bayangkara. Pasukan yang telah terlatih dan terdidik mendekati sempurna.

Mahapatih Gajah Mada dan pasukannya bekerja keras mencari strategi perang dalam menghadapi pasukan musuh yang jumlahnya cukup banyak.

Peresepsian Raksa terhadap Kidung Sunda dengan peresepsian pencipta Kidung Sunda yang diterjemahkan oleh Hasan Wirasutisna terhadap terjadinya Perang Bubat menunjukkan perbedaan yang sangat mencolok. Pencipta Kidung Sunda yang meresepsi peristiwa Perang Bubat pada abad ke-16 memandang kepergian rombongan Raja Sunda memenuhi pinangan Raja Majapahit, sedangkan Raksa yang meresepsi peristiwa Perang Bubat pada abad ke 22 atau tepatnya tahun 2012 memandang tujuan keberangkatan rombongan Raja Sunda Galuh yang disertai istri dan putrinya serta membawa sejumlah prajurit ke Jawa sengaja akan berperang. Raksa sebagai peresepsi dari generasi modern yang horizon harapannya lebih luas dan hidup pada zaman modernisasi dapat menilai alat transportasi yang digunakan rombongan Raja Sunda sebagai produksi Sunda Galuh atau mungkin saja dibeli dari Kerajaan Sriwijaya yang pada saat itu sudah mempunyai teknologi maritim yang unggul.

Resepsi terhadap Perang Bubat yang menarik dan berbeda dari yang lain adalah yang ditulis oleh Ramadhan (2017: 16) menyoroti penamaan Bhayangkara untuk Korps Kepolisian RI yang berasal dari nama pasukan khusus yang dipimpin oleh Gajah Mada pada saat Perang Bubat.
Ramadhan menerima adanya benang merah antara Bhayangkara saat ini dengan Bhayangkara pada masa Kerajaan Majapahit. Realitas polisi saat ini mengingatkan kembali pada sepak terjang Patih Gajah Mada beserta pasukan Bhayangkaranya yang berambisi untuk menaklukkan seluruh Nusantara. Bahkan, pada masa kejayaannya hampir seluruh kerajaan di Asia Kecil berada di bawah kekuasaan Kerajaan Majapahit. Penaklukkan tersebut harus terhenti ketika terjadi tragedi pembantaian rombongan pengantin dari Kerajaan Sunda di Tanah Bubat oleh ambisi Gajah Mada yang tidak rela akan adanya pernikahan antara putri kerajaan musuhnya dengan Raja Majapahit. Pada masa itu Kerajaan Sunda merupakan kerajaan yang sulit untuk dikalahkan.

Raden Wijaya sebagai Raja Majapahit merasa kecewa dan dikhianati hingga harus memberi sanksi pada panglima dan pasukannya. Kisah Gajah Mada dan pasukan Bhayangkara pada masa penaklukkan Majapahit seperti terulang kembali pada masa modern. Polisi kini lebih ditakuti oleh masyarakat karena cenderung melakukan tindakan di luar wewenangnya. Demikian penerimaan Ramadhan dalam penafsiran ulang terhadap peristiwa Perang Bubat.

\section{Resepsi Sastra terhadap Unsur Luar Karya}

Yang dimaksud resepsi sastra secara sosiologis adalah tanggapan pembaca terhadap unsur di luar struktur sastra seperti pengarang dan pembaca. Firdaus (2006: 3) melaporkan hasil diskusi dan peluncuran novel ke-4 tentang Perang Bubat karya Langit Kresna Hariadi (LHK) yang berjudul Gajah Mada: Perang Bubat yang diselenggarakan oleh Universitas Parahyangan dalam rangka "Pekan Sejarah". Dalam diskusi tersebut peresepsian lebih diarahkan kepada pengarang. Diungkapkan bahwa LKH di dalam novelnya menyampaikan keberpihakan bukan kepada dua kubu yang 
berkonflik, melainkan kepada nalar dan dan logika yang diproses dari fakta-fakta sejarah, misalnya saat di lapang Bubat, pihak mana yang menyerang lebih dulu? Tentunya nalar dan logika akan berpihak pada pihak yang tersinggung yang menyerang terlebih dahulu.

LHK juga menggambarkan penokohan Gajah Mada sebagai orang yang bijkasana, strategis, dan taktis dalam bidang politik kemiliteran. Digambarkan pula bahwa sikap Gajah Mada itu selalu diselaraskan dengan sumpah saktinya yang termasyur.

Perepsesian sastra yang mempertimbangkan pengarang juga disampaikan oleh Imran (2009: 2) yang meresepsi novel tentang Perang Bubat yang berjudul Perang Bubat karya Aan Merdeka Permana. Resensi tersebut berjudul "Perang Bubat yang Lain" yang dipublikasikan pada tanggal 31 Mei 2009 di surat kabar Pikiran Rakyat. Judul artikel mengisyaratkan ada peristiwa yang berbeda atau lain dengan yang sudah ada. Peresensi mengatakan bahwa ketika imajinasi kolektif ihwal Perang Bubat itu hadir dari sudut pandang narasi yang lain, hasilnya pun tidak sama.

Dalam novel ini Aan menggambarkan bahwa di balik perang tersebut ternyata menyimpan kisah cinta antara Gajah Mada dan Dyah Pitaloka. Selain itu disebutkan bahwa Prabu Linggabuana dan Dyah Pitaloka sesungguhnya tidaklah gugur di Bubat. Diungkapkan pula latar belakang Gajah Mada yang berasal dari Banten serta keturunan Cina. Semasa muda Gajah Mada bernama Ramada. Ia pernah mengabdi di Kerajaan Sunda Kawali.

Peresensi menjelaskan pula tentang sebuah narasi yang mengatakan bagaimana perang serta peristiwa tragis itu terjadi. Perang Bubat terjadi bukan semata-mata ambisi politik Gajah Mada, melainkan adanya intrik politik di kalangan istana.

Itulah narasi lain tentang Perang Bubat yang diangkat Aan Merdeka
Permana dalam novelnya Perang Bubat yang diterbitkan oleh penerbit Qanita.

Narasi lain yang dilakukan Aan tidak hanya peristiwa tentang Perang Bubat seperti yang termaktub dalam berbagai sumber sejarah seperti Pararaton, Kidung Sunda atau Kidung Sundayana.

Imran juga menerangkan bahwa ketidaklaziman ini bukannya tidak disadari oleh Aan Merdeka Permana. Berbeda dengan para pengarang lain yang menulis novel yang berkonteks sejarah lewat berbagai riset dan pembacaan berbagai referensi. Aan Merdeka Permana menulis novel Perang Bubat berdasar pada sumber lisan sejumlah orang dalam perjalanannya dari Bandung Selatan, Garut sampai ke Bubat di Kecamatan Trowulan, Mojokerto, Jawa Timur.

Bahkan, kisah ini bertolak belakang dengan babon sejarah. Hal ini tentu tidak perlu dirisaukan karena data yang ditemukan tidak memiliki bukti otentik seperti yang diisyaratkan ahli sejarah.

Aan Merdeka Permana secara tegas mengatakan bahwa novel Perang Bubat bukan novel sejarah. Meskipun begitu, novel ini dipandang kontroversial. Dapat saja novel ini mengidentifikasi diri sebagai karya fiksi, tetapi ia bertutur tentang peristiwa yang ada dalam berbagai sumber tertulis dan menjadi bagian utuh dalam imajinasi kolektif masyarakat.

Mahayana (2009: 1-2) meresepsi novel Perang Bubat: Tragedi di Balik Kisah Gajah Mada dan Dyah Pitaloka karya Aan Merdeka Permana. Dalam pengantar buku itu Mahayana menyampaikan bahwa novel tersebut mengangkat kembali peristiwa Perang Bubat dalam jalinan kisah yang memukau, filmis, dan asyik.

Kritikus sastra dari FIB-UI itu mengatakan bahwa Perang Bubat adalah peristiwa sejarah yang menjadi kontroversi di antara budaya Sunda dan Jawa. Kontroversi ini melahirkan berbagai prasangka di antara keduanya. Misalnya, mengapa rombongan Kerajaan Sunda yang datang ke Bubat, Majapahit untuk 
mengantar Putri Dyah Pitaloka menjadi istri Prabu Hayam Wuruk diserang pasukan Majapahit yang bersenjata lengkap?

Peran Mahapatih Gajah Mada dalam tragedi itu juga menjadi bahan perdebatan. Ambisi Gajah Mada untuk menyempurnakan Sumpah Palapa dengan menaklukkan Sunda? Ataukah ia sebenarnya hanya dikambinghitamkan oleh orang-orang yang dengki atas ketenarannya? Benarkah sesungguhnya di antara Dyah Pitaloka dan Gajah Mada pernah terjalin hubungan asmara?

Berbagai sumber sejarah memberikan versi yang berbeda tentang kejadian tersebut. Penulis novel ini, seorang pemerhati Sejarah Sunda, menggali sumber-sumber sastra lisan yang tersebar di berbagai daerah, mulai dari Bandung Selatan, Garut, Lawang Sumber di tepian Kota Surabaya hingga ke Bubat di Trowulan, Kabupaten Mojokerto.

Hasilnya adalah kisah Perang Bubat yang sangat berbeda dari versi yang selama ini kita ketahui dari sejarah.

\section{PENUTUP}

Dapat disimpulkan bahwa Perang Bubat, peristiwa sejarah yang terjadi pada abad ke-14 itu mendapat tanggapan dan sambutan yang besar dari masyarakat Indonesia, khususnya Sunda dan Jawa.

Pada saat perang itu pecah pada abad ke-14, tidak ditemukan resepsi atau tanggapan dari masyarakat. Tanggapan tercatat setelah peristiwa itu berlalu dua abad, yaitu pada abad ke-16.

Tanggapan atau resepsi masyarakat dan pembaca sastra terhadap peristiwa Perang Bubat menjadi tiga kelompok, yaitu Resepsi Perang Bubat dan pengaruhnya Lahirnya Karya Baru, Resepsi Sastra terhadap Unsur Karya, dan Resepsi Sastra terhadap Unsur Luar Karya.

Peristiwa Perang Bubat dianggap memberi pengaruh terhadap perkembangan karya sastra yang memiliki unsur sejarah, misalnya Sang Mokteng Bubat (1991) karya Yoseph Iskandar.
Di samping itu, peristiwa Perang Bubat juga mendapat sambutan atau tanggapan yang luar biasa dari pengarangpengarang modern yang tertuang dalam bentuk novel. Hadirnya novel-novel modern yang sumber penciptaannya dari peristiwa Perang Bubat membuka peluang bagi pembaca dalam menambah horizon harapan tentang peristiwa Perang Bubat.

Lahirnya karya-karya sastra daerah dan novel-novel modern yang bersumber pada peristiwa Perang Bubat tersebut di sisi lain menimbulkan perbincangan dan perdebatan yang ditandai dari munculnya resesnsi-resensi, kritik, artikel-artikel yang muncul di surat kabar dan majalah yang merespon novel-novel tersebut.

Hadirnya resepsi peristiwa Perang Bubat dalam wujud novel ini juga membuka peluang bagi para peneliti sastra untuk melakukan berbagai kajian terhadap novel-novel tersebut, termasuk ke dalamnya kritik sastra terhadap Perang Bubat.

Resepsi atau tanggapan terhadap sturktur karya cukup beragam, seperti terhadap tokoh, alur, latar, dan sudut pandang pengarangnya. Yang menjadi pusat perhatian adalah tokoh Gajah Mada, Dyah Pitaloka, Raja Sunda, dan Hayam Wuruk. Gajah Mada sebagai tokoh sentral diresepsi memiliki karakter yang berbeda. Perbedaan penggambaran tokoh Gajah Mada dan juga tokoh-tokoh lainnya sangat bergantung pada ruang, waktu, dan horizon harapan si peresepsi. Kemudian tanggapan terhadap sudut pengarang juga cukup mendapat perhatian. Pengarang sebagai pencipta karya dalam proses kreatifnya cukup dipengaruhi oleh latar belakang budayanya.

Sementara itu, tanggapan terhadap unsur di luar struktur karya lebih didominasi dengan tanggapan terhadap pengarang, budaya, dan situasi yang terjadi pada saat Patih Gajah Mada Berjaya di Kerajaan Majapahit dengan pasukan tentaranya yang dinamai Bhayangkara. Yang sekarang namanya digunakan sebagai Korps Kepolisisian RI. 


\section{DAFTAR SUMBER}

\section{Jurnal dan Laporan Penelitian}

Abdullah, Imran T. 1991.

"Resepsi Sastra Teori dan

Penerapannya." Humaniora No. 2(199

1): 71--76.

Asmalasari, Devyanti. 2010.

"Peristiwa Bubat dalam Novel Perang

Bubat Karya Yoseph Iskandar dan Novel Gajah Mada, Perang Bubat Karya Langit Kresna Hariadi (Kajian Sastra Bandingan)." Metasastra: Jurnal Penelitian Sastra 3(Nomor 2, Desember 2010): 93--105.

Hidayat, Sarip. 2015.

"Pandangan Dunia Orang Sunda dalam

Tiga Novel Indonesia tentang Perang

Bubat." Metasastra: Jurnal Penelitian

Sastra: 105-20.

http://ejurnalbalaibahasa.id/index.php/me tasastra.

Pradipta, Inggar. 2009.

"Resensi dan Resepsi Sastra."

Universitas Indonesia.

Ramadhan, Mochamad Sigit dan Aminuddin

T.H. Siregar. 201

"Bhayangkara (Tafsir Visual Peristiwa Sejarah Perang Bubat" J. Vis. Art \& Design, Vol. 9. No. 1, 2017, 14-27, ITB, Bandung

Sastriyani, Siti Hariti. 2001.

"Karya Sastra Perancis Abad ke-19 Madame Bovary Dan Resepsinya Di Indonesia." Humaniora XII, No. 3: 252-29.

Wati, Noor Rahmi. 2013.

“Analisis Resepsi Pembaca Cerpen Koroshiya Desunoyo Karya Hoshi Shin 'Ichi ( Studi Kasus terhadap 15 Orang Jepang )." Japanese Literature 2(Nomor 3, Tahun 2013): 1--13.

\section{Buku}

Mahayana.Maman S. 2009.

"Perang Bubat: Tragedi di Balik Kisah Cinta Gajah Mada dan Dyah Pitaloka." In Qanita, 339.

\section{Surat Kabar/Majalah}

Anugrah, Yudi. 2015. "Perang Bubat Dalam Memori Orang Sunda." : Historia, 22 Mei 2015, h. 1-4.

Firdaus, Yulian. 2006.

Diskusi Perang Bubat, Unpar. Bandung. Nusantara, 23 Desember 2006.

Imran, Ahda. 2009.

"Perang Bubat Yang Lain." : 1-5.

Khazanah, Pikiran Rakyat, Minggu, 31 Mei 2009.

Sulwesi, Endah. 2006.

DYAH PITALOKA : Senja di Langit Majapahit. Bandung. Klub Sastra Bandung

\section{Internet}

Raksa, Aji. 2012. http://ajiraksa.blogspot.com/2012/05/te ori-perang-bubat-analisa-kitab-kid. (diakses tanggal 17 Mei 2017).

Sumarjo, Jakob. 2013.

"Sekitar Perang Bubat". dalam http://borobudurwriter.com

(diakses pada tanggal 17 Mei 2017) 